\title{
ROBERT BURTON'S ANATOMY OF MELANCHOLY
}

\author{
By W. D. Nicol, F.R.C.P. \\ Physician and Lecturer in Psychological Medicine, Royal Free Hospital; Physician Superintendent, Horton Hospital, \\ Epsom

\section{' Melancholy is a kind of dotage without a fever, having for its ordinary} \\ companions fear and sadness, without any apparent occasion.'
}

In $186 \mathrm{I}$ an article appeared in Blackwood, in which the writer amusingly introduces Burton to the well-known British traveller, Leo Rusticus, Esq., who is visiting Oxford with his interesting daughters about Commemoration time. They must need do the sights, hence their visit to Chrish Church Cathedral, " the ugliest possible of collegiate churches,' but at least a cathedral. Here they are shown what little there is to see by the verger, who points out 'in the north aisle, high up against a pillar, a small bust, with a Latin inscription underneath, and a queer-looking diagram stuck rather awkwardly on one side of it, which the young ladies will probably at the first glance take for a sun dial, but which is in truth an astrological calculation of a nativity.' 'Burton, sir,' says the verger, ' author of the Anatomyformerly student of this house.' The young ladies who conclude he must have been some medical celebrity, are quickly informed by the father, who explains, ' Anatomy of Melancholy, you know, my dears,' whereupon the verger takes up the narrative, "Yes sir, he was a very melancholy gentleman and is supposed to have destroyed himself, and that's his horro-scope.' The author of this article continues to reflect how papa knows the book is on his shelves at home, it lies there unread ; indeed how many Fellows of the College have any personal acquaintance with this book. As a boy I remember the volume on my father's shelves.

Before we discuss the book, let us enquire what we know of the author. Unfortunately our knowledge is somewhat scant, though there appear a few biographical details scattered here and there. We learn more from other sources; his brother, William, who wrote a Description of Leicestershire, tells of his family, who boasted an ancient lineage. Anthony à Wood (1721) in Athenae Oxonienses provides perhaps more biological material. Robert Burton was born at Winsley in Leicestershire, the

From a lecture delivered in 1947 to the Listerian Society of King's College Hospital. fourth of nine children, in 1577 . A 'Grammar scholar' at Sutton Coldfield in Warwickshire at first, after which he entered Brasenose College, Oxford, and then Christ Church. After taking a degree he continued in residence as student tutor and college librarian at Christ Church where he spent the rest of his life. It is recorded that he was Vicar of St. Thomas's, Oxford, and later he was given the living of Seagrave in his own county. The Anatomy is dedicated to George Lord Berkeley, the patron of this gift; at some other time he probably had a preferment at Walsby in Lincolnshire. Paul Jordan-Smith in his Bibliographia Burtoniana is responsible for throwing an interesting light on Burton's secular life; apparently this cleric and divine was for three years one of the Clerks of the Market of Oxford. This discovery was quite accidental, through the chance purchase of a copy of the Anatomy, interleaved and loaned at one time to Professor Murray ' for the use of the Dictionary.' The book was previously the property of Mr. George Parker of the Bodleian Library, who had noted the fact of Burton's appointment to the Market. This is important and gives us a clue to the non-clerical side of Burton's personality and character.

He died on January 25 th, 1639 , so near to the exact time he had predicted that idle rumour had it that he hanged himself to prove a prophet. This is unlikely, as a felo-de-se would have precluded his burial in Christ Church Cathedral.

Anthony à Wood, who as a child might have known him, gives this character of him (Evans : (The Psychiatry of Robert Burton). 'He was an exact Mathematician, a curious Calculator of Nativities, a general read scholar, a thro'-pac'd Philologist, and one that understood the surveying of Lands well ... I have heard some of the Antients of Christ Church often say that his Company was very merry, facete, and juvenile, and no Man in his time did surpass him for his ready and dextrous interlarding his common discourses among them with Verses from the Poets, or Sentences from classical Authors. Which being then all the 
fashion in the University, made his Company more acceptable.' Bishop Kennett in writing of the Anatomy says, "The author is said to have laboured long in the Writing of this Book to suppress his own Melancholy, and yet did but improve it. ... In an interval of vapours he could be extremely pleasant, and raise laughter in any Company. Yet I have heard that nothing at last could make him laugh, but going down to the Bridge-foot in Oxford, and hearing the bargemen scold and storm and swear at one another, at which he would set his Hands to his sides and laugh most profusely.' So much for our limited knowledge of this strange cleric, though he doubtless reveals himself and records his many frustations in the course of his treatise of the Anatomy.

It was first intended that the book should be published anonymously. 'Suppose the man in the moon, or whom thou wilt, to be the author.' The first edition appeared in 1621 under the pseudonym of Democritus Junior. His desire for anonymity was hardly sincere, as he signed his name to the postscript of the first edition and though it was withdrawn in subsequent editions, the third edition was furnished with a portrait of the author in the centre of Le Blon's title page. The book was undoubtedly a success, 'The first, second and third editions were suddenly gone, eagerly read.' Though the author added many alterations in subsequent editions, he found it tiring : in the last edition to be produced in his lifetime, he writes: 'Although this be a Sixth Edition in which I should have been more accurate, corrected all those former escapes, yet it was magni laboris opus, so difficult and tedious, that as Carpenters do find out of experience, 'tis much better build a new sometimes than repair an old house. . . . But I am now resolv'd never to put this treatise out again. Ne quid nimis. I will not hereafter add, alter or retract, I have done. The last and greatest exception is, that I being a divine have medled with physick.'

His style is difficult and his arguments not easy to follow. 'I resolve, if you like not my writing, go read something else.' 'I neglect phrases, and labour wholly to inform my reader's understanding, not to please his ear; 'tis not my study or intent to compose neatly, which an Orator requires, but to express myself rapidly and plainly as it happens.' ' I am but a smatterer, I confess, a stranger, here and there I pull a flower; I do easily grant, if a rigid censurer should criticize on this which I have writ, he should not find three sole faults, as Scaliger in Terence, but 300.' The book is amazing for its encyclopaedic knowledge of classical, historical and contemporary literature of the Western World available to a scholar who had access not only to his college library, but to the Bodleian. One shudders to contemplate what Burton's thoughts would have been had he lived in our time. At the beginning of the 17 th century ' in this scribbling age' he deplored the mass of books extant. 'What a catalogue of new books all this year. ... As already, we shall have a vast chaos and confusion of Books, we are oppressed with them, our eyes ache with reading, our fingers with turning.'

He wanted to write the whole treatise in Latin, but fortunately for posterity his publishers insisted on our English version. "Any scurrile pamphlet is welcome to our mercenary Stationers in English, they print all, but in Latin they will not deal.' Even so most of the quotations are in Latin and occasionally the author breaks off into Latin for the space of several pages. His description of sexual perversions is not suited to the English language 'I spare to English that which I have said.' All prescriptions are in Latin, so that the unlearned reader will not be tempted to practise on himself. Suggested reforms, long overdue, in the University are likewise hidden behind a cloak of Latin.

Why does Burton write under the name of Democritus Junior and why does he elect to write about Melancholy? Before he actually deals with his subject, by way of introduction there is a very lengthy preface entitled 'Democritus to the Reader.' Apart from being explanatory and somewhat revealing, as far as the author himself is concerned, it is full of satire and wit. He models himself on Democritus, because this Greek philosopher was visited in his garden at Abdera by Hippocrates, who relates how he found Democritus ' under a shady bower, with a book on his knees, busy at his study, sometimes writing, sometimes walking. The subject of his book was melancholy and madness, about him lay the carcases of many several beasts newly by him cut up and anatomized, not that he did contemn God's creatures but to find out the seat of this atra bilis or melancholy, whence it proceeds, and how it was engendered in men's bodies, to the intent he might better cure himself, and by his writings and observations teach others how to prevent and avoid it. Democritus junior is bold to imitate.' Burton says, 'I writ of melancholy, by being busy to avoid melancholy. There is no greater cause of melancholy than idleness, no better cure than business.' Doubtless he was a sufferer himself, ' to ease my mind in writing, for I had gravidum, cor, foetum caput, a kind of imposthume in my head, which I was very desirous to be unladen of.' He debates whether he should have written on some other subject on humanity or divinity, but ' there be so many books in that kind (divinity), so 
many commentators, treatises, pamphlets, expositions, sermons, that whole teams of oxen cannot draw them.' Moreover he adds ' but at this time I was fatally driven upon this rock of melancholy, and carried away by this by-stream, which, as a rillet, is deducted from the main channel of my studies.' He defends himself for writing on a medical subject, at the expense of the miserable conditions in the Church. "If any physician in the meantime shall infer and find himself grieved that I have intruded into his profession, I will tell him in brief. I do not otherwise by them, than they do by us. If it be to their advantage, I know many of their sect which have taken orders in hope of a benefice, 'tis common transition, and why not a melancholy divine, that can get nothing by simony, profess Physick ?' Thomas Linacre, first President of the College of Physicians, in his old age took orders. He draws a sorry picture of clerical life. 'Many poor country vicars, for want of other means, are driven to their shifts ; to turn mountebanks, quack salvers, empiricks, and if our greedy patrons hold us to such hard conditions, as commonly they do they will make most of us work at some trade, as Paul did, at last turn taskers, maltsters, costermongers, graziers, sell Ale as some have done or worse.'

He makes a plea for a closer liaison between the cleric and the physician. 'It is a disease of the soul on which I am to treat and as much appertaining to a Divine as to a Physician. A good divine either is or ought to be a good physiciana spiritual Physician at least. They differ but in object, the one of the body, the other of the soul, and use divers medicines to cure.' 'I could not find a fitter task to busy myself about,' he continues, ' a more apposite theme, so necessary, so commodious, and generally concerning all sorts of men, that should so equally participate of both and require a whole physician. A Divine in this compound mixed malady can do little alone, a Physician in some kinds of melancholy much less, both make an absolute cure. And 'tis proper to them both and I hope not unbeseeming me, who am by profession a Divine, and by mine inclination a Physician.' He proceeds to argue his theme, by contemporary illustrations. Europe, as now, was then in a state of turmoil, in fact his remarks may well be applied to the events of recent years. 'What would Democritus have said,' he asks ' to see, hear and read so many bloody battles . . . so many thousands slain at once, such streams of blood able to turn mills ... to make sport for princes, without any just cause... whilst statesmen themselves in the meantime are secure at home, pampered with all delights and pleasures, take their ease, and follow their lusts, not considering what intolerable misery poor soldiers endure, their often wounds, hunger, thirst, etc., the lamentable cases, torments, calamities and oppressions, that accompany such proceedings, they feel not, take no notice of it. So wars are begun, by the persuasion of a few debauched, hair-brain, poor, dissolute, hungry captains, parasitical fauners, unquiet Hotspurs, restless innovators, green heads, to satisfying one man's private spleen, lust, ambition, avarice, etc. Kingdoms, provinces and politick bodies are all subject to this disease of melancholy, as well as private men. Beroaldus will have drunkards, afternoon men, and such as more than ordinarily delight to drink to be mad. The first pot quencheth thirst ... the second makes merry, the third for pleasure, quarta ad insanium, the fourth makes them mad. If this position be true, what a catalogue of mad men shall we have! What shall they be that drink four times four ?'

To return to the problems of nations he maintains that such as are sick and melancholy there is need for reform. "The most frequent maladies are such as proceed from themselves, as first when religion and God's service is neglected, innovated or altered, where they do not fear God, obey their Prince, where Atheism, Epicurism, Sacrilege, Simony, etc., and all such impieties are freely committed, that country cannot prosper.' The England of Robert Burton's day must have been in need of export trade as surely as today; he deplores the export of our best commodities beyond the seas, only to be sent back to us at dear rates. He advocates a system of town planning, he almost prophesies the regionalization of this country into 12 or 13 regions, but he is at least mindful of our uncertain climate and suggests a site about latitude $45^{\circ}$ is preferable to our northern zone. A national health service is forecast-' hospitals of all kinds, for children, orphans, old folks, sick men, mad men, soldiers, pest houses, etc., not built precario (only to last a short time) or by gouty benefactors,' but 'hospitals so built and maintained, not by collections, benevolences, donories, for a set number (as in ours) just so many and no more at such a rate, but for all those who stand in need, be they more or less, and that $e x$ publico oerario, and so still maintained.'

From commonwealths and cities he descends to families, "which have as many corrosives and molestations, as frequent discontents as the rest.' Unhappy marriages are responsible for melancholy. 'A good, honest, painful man many times hath a shrew to his wife, a sickly dishonest, slothful, foolish, careless woman to his mate, a proud, peevish flirt, a liquorish, prodigal quean, and by that means all goes to ruin; or if they differ in nature, he is thrifty, she spends all, he wise, she sottish and soft; what agreement can 
there be ? What friendship ? Instead of mutual love, kind compellations, whore and thief is heard, they fling stools at one another's heads.' After castigating countries, nations, commonwealths, families and individuals he enquires of the reader, 'Who am I that so boldly censure others, have I no faults ? Yes, more than thou hast, whatsoever thou art. I confess it again, I am as foolish, as mad as any one. My purpose and endeavour is, in the following discourse, to anatomize this humour of melancholy, through all his parts and species, as it is an habit or an ordinary disease, and that philosophically, medicinally, to shew the causes, symptoms and several cures of it, that it may be the better avoided; moved thereunto for the generality of it and to do good, it being a disease so frequent, ... . as few there are that feel not the smart of it. ... Being then it is a disease so grievous, so common, I know not wherein to do a more general service, and spend my time better, than to prescribe means how to prevent and cure so universal a malady, an epidemical disease that so often, so much, crucifies the body and the mind.'

After this long preface, one of the best parts of the book, the author proceeds to get down to his thesis. It is most carefully planned, with three partitions, which again are subdivided into members or sections and subsections. The first partition deals with the nature of melancholy, its causes and its symptoms ; the second with the cure of melancholy, while the third partition, by far the largest is devoted to love melancholy, with sections on religious melancholy, jealousy and despair. Each partition is prefaced by a synopsis, with the most elaborate classifications and subheadings, such as would challenge any synopsis series in our contemporary medical manuals. Sandwiched in these various sections are three digressions, one on anatomy, one on 'air rectified' and one on the nature of supernatural beings. .

It is a pity that this careful treatment of his subjects leads to much repetition, which becomes wearisome to the reader. "I had rather repeat words ten times than omit anything.' The quotations from classical, European and contemporary literature are legion. Evans in his monograph on the Psychiatry of Robert Burton writes, "He had to thread his way through some remarkable material. Seventeenth century medicine (or rather I6th century, for the Anatomy was written too early in the 17 th century to benefit by anything but the previous century's learning) was an amalgam of superstition and magic with common-sense observations. It incorporated old wives' tales and folklore with remedies tested in practice, and seemed not to distinguish the one from the other. The great physicians were still the ancients and their Arabic successors, whose teaching, erroneous in many respects, had been vitiated by false translations, textual corruptions, and the embroideries of generations of charlatans. Burton had neither the training nor the knowledge that would have been required to sift this mass and separate the false from the true. But then, nor had anyone else in his day.'

To return to the first partition, let us see what he has to say about symptomatology. He makes it quite clear than melancholy is not to be confused with madness or what we would call mania; moreover he is aware that the same patient may exhibit one or other symptom at different times, what we mean by the term manicdepressive insanity. He quotes the Abderites as condemning Democritus for a mad man, ' because he was sometimes sad, and sometimes again profusely merry.' He defines madness ' to be a vehement dotage, or raving without a fever, far more violent than melancholy, full of anger and clamour, horrible looks, actions, gestures, troubling the patients with far greater vehemency both of body and mind, without all fear and sorrow, with such impetuous force and boldness, that sometimes three or four men cannot hold them.' Burton distinguishes between melancholy proper and states of melancholy. Melancholy fits "are but improperly so called, because they continue not, but come and go, as by some objects they are moved. This melancholy of which we are to treat, is an habit, morbus senticus or chronicus, a chronick or continute disease, a settled humour, as Aurelianus and others call it, not errant, but fixed ; and as it was long increasing, so, now being (pleasant or painful) grown to an habit, it will hardly be removed.'

Melancholy then is ' a kind of dotage without a fever, having for its ordinary companions fear and sadness, without any apparent occasion.' Apprehension and general retardation that is typical of the disease are aptly described, so too ideas of unworthiness and delusions. "By reason of those continual fears, griefs, and vexation he is dull, heavy, lazy, restless, unapt to go about any business.' 'Imminent danger, loss, disgrace, still torment others, etc., they are all glass, and therefore will suffer no man to come near them ; they are all cork, as light as feathers ; others are as heavy as lead; some are afraid their heads will fall off their shoulders, that they have frogs in their bellies.' 'If two talk together, discourse, whisper, jest or tell a tale in general, he thinks presently they mean him, applies all to himself.' The cyclical nature of the disease is recognized; one 'hath a most grievous fit once in seven years, once in five, another in three or four.' Suicide is referred to: 'Seldom this malady,' he writes, 'procures death, except (which is the greatest, 
most grievous calamity, and the misery of all miseries) they make away themselves, which is a frequent thing and familiar amongst them.'

With regard to physical signs he recognizes the importance of ' costivness' and 'keeping in of our ordinary excrements,' the suppression too of 'the monthly issues in women.'

The fixed looks, ' neglect habit' are mentioned of the woman portrayed in the picture by Albertus Durer.

The etiology of this disorder is studied and analysed with equal precision ; the list of possible causes is as protean as the variety of symptoms ; in fact no wonder. Burton comes to the conclusion 'Who is free from melancholy? Who is not touched more or less in habit of disposition ?' No man living is wholly free.

The first cause of melancholy is God Himself ; the concepts of biblical doctrines held in the $17^{\text {th }}$ century afforded abundant evidence that the punishment of sin was responsible for making sinners mad. Other supernatural causes are adduced, wherefore a long digression on the nature of spirits, bad angels or devils, witches and magicians of which more later. Stars, too, and other heavenly bodies, especially the moon, are causes of melancholy. The list of etiological factors is so long, that Burton found difficulty in deciding which if any was the main cause; yet there is some sound common sense to be found in his meanderings, while much else is equivocal, confused and far fetched, but not without providing much amusement for the reader.

Heredity as an etiological factor is stressed, the innate constitutional predisposition realized. We inherit our infirmities from our parents; though it is doubtful if the transmigration of nations every 600 years is the real remedy 'to amend and purify their blood, as we alter seed upon our land.' A plea for eugenics is put forward. 'How careful should we be in begetting of our children.'

Diet is so restricted that, to follow his precepts, these days of rationing would indeed be liberal. Beef breeds gross melancholy blood, pork is unfit for such as live at ease, all venison is melancholy, so is hare; milk and all that comes of milk, as butter and cheese increase melancholy. Poultry of all kinds is forbidden; herbs, roots and pulse are nought. But heart wine (not black wines) is much commended, if it be moderately used.' 'Beer, if it be over new or over stale, over strong, or not sod, smell of the cask, sharp or sour, is most unwholesome.... But let them say as they list, to such as one accustomed unto it, 'tis a most wholesome and a pleasant drink, it is more subtile and better for the hop that rarefies it, hath an especial virtue against melancholy. All cakes, fritters, pancakes, pies, sausages and those several sauces . . . these do generally, ingender gross humours, fill the stomach with crudities, and all those inward parts with obstructions.'

Burton anticipates Freud by 300 years, when we read what he has to say about sexual abstinence' stale maids, nuns and widows, they are melancholy in the highest degree, and all for want of husbands.' Other authorities are quoted in evidence of the evils brought on by over-indulgence, which likewise causes melancholy. Jacchinus ' instanceth in a Patient of his, that married a young wife in a hot summer, and so dried himself with chamber-work, that he became in short space from melancholy mad.' Any physical exercise, if it be unreasonable, violent or overmuch is bad, but on the other hand let it be a warning to those of you who are lazily inclined. 'Idleness (the badge of gentry) or want of exercise, the bane of body and mind, the nurse of naughtiness, stepmother of discipline, the chief author of all mischief, one of the seven deadly sins, and a sole cause of this and many other maladies.' 'Thus much I dare boldly say,' he continues, ' he or she that is idle, be they of what condition they will, never so rich, so well allied, fortunate, happy, let them have all things in abundance, and felicity, that heart can wish and desire, all contentment, so long as he or she or they are idle, they shall never be pleased, never well in body and mind, but weary still, sickly still, vexed still, loathing still, weeping, sighing, grieving, suspecting, offended with the world, with every object, wishing themselves gone or dead.... And this is the true cause that so many great men, Ladies and Gentlewomen, labour of this disease in Country and City.'

Shame is another cause of melancholy, as witness the sad story of ' a grave and learned Minister,' at Alkmaar in Holland, who 'was (one day as he walked in the fields for his recreation) suddenly taken with a lask or looseness, and thereupon compelled to retire to the next ditch ; but being surprised at unawares by some Gentlewomen of his Parish wandering that way, was so abashed, that he did never after show his head in publick, or come into the Pulpit, but pined away with Melancholy.'

To devotees of race meetings and dog tracks or cards let Galatoeus' observation be a warning: "If they win, no men living are so jovial and merry, but if they lose, though it be but a trifle ... they are so cholerick and testy that no man may speak with them, and break many times into violent passions, oaths, imprecations and unbeseeming speeches, little differing from mad men for the time.' 
Study is a cause and we read a long discourse on the miserable conditions in the Church, offered by ' griping' patrons. A sermon 'publickly preached at Paul's Cross by a grave Minister then, and now a Reverend Bishop of this land ' is quoted in extenso, "What Christian will be so irreligious, to bring up his son in that course of life, which by all probability and necessity, enforcing to sin, will entangle him in Simony and perjury.' Burton asks what is the alternative 'let us give over our books, and betake ourselves to some other course of life . . . let's turn soldiers, sell our books, and buy swords, guns, and pikes . . . turn our Philosophers' gowns into millers' coats, leave all and rather betake ourselves to any other course of life, than to continue longer in this misery.'

The whole of the second partition is devoted to the cure of melancholy. Unlawful cures practised by the devil and his ministers, sorcerers, witches, magicians, etc., are at the outset deprecated, ' not to be tolerated or endured.' The first of all cures is prayer to God, nevertheless 'we must seek to and rely upon the Physician.' $\mathrm{He}$ warns his readers of the quack, many mountebanks, quack salvers, empiricks abound in almost every street and village. His chief desideratum of the Physician is honesty, so many he regrets 'to get a fee, will give Physick to everyone that comes, when there is no cause.' Another caution is noted, the need for accurate diagnosis. To the patient, he gives advice, ' be not too nigardly miserable of the purse or think it too much that he bestows upon himself, and to save charges endanger his health.' Above all a patient must have confidence in his physician and have 'sure hope' that he can help him; he must have perseverance and obedience too, and ' not to change his Physician.' The accepted form of therapy for melancholy came under three headings-Diet or Living, Apothecary, Chirurgery. "Make a melancholy man fat, as Rhasis saith and thou hast finished the cure.' Occupation therapy is advocated. We have already heard his censures on idleness. Outdoor exercise, 'Recreations of the mind within doors, books, maps, pictures,' such studies will expel idleness and melancholy. In praise of books he refers to King James's visit to Oxford in 1605 , how he went to view that famous library renewed by Sir Thomas Bodley. 'If I were not a King, I would be a University man.'

For women, ' instead of laborious studies, they have curious needleworks, cutworks, spinning, home-lace and many pretty devices of their own making, to adorn their houses, cushions, carpets, chairs, stools. ...'

To alleviate the sorrow of these patients, some feigned lie, strange news, witty device, artificial invention, it is not amiss to deceive them. Philodotus the physician cured a melancholy king who thought he had no head, ' by putting a leaden cap thereon.' Other remedies are suggested and one, especially, which might well be heeded by the urologists. 'The pleasantist dotage that ever I read, saith Lurentius, was of a Gentleman at Senes in Italy, who was afraid to piss, lest all the Town should be drowned; the Physicians caused the bells to be rung backward, and told him the Town was on fire, whereupon he made water, and was immediately cured.'

Burton is sceptical of apothecary physick : 'Physicians kill as many as they save, and who can tell how many murders they make in a year, that may freely kill folks, and have a reward for it ? and according to the Dutch proverb, a new Physician must have a new Church-yard ; and who daily observe it not ?' Of herbs, 'Borage and Bugloss may challenge the chiefest place.' Purgatives both ' upwards' and 'downwards' are advocated, white hellebore or sneezing powder, aloes and, last but not least, tobacco, 'a good vomit, I confess, a virtuous herb, if it be well qualified, opportunely taken and medicinally? used.' Of chirurgical remedies leeches take firse place ; blood letting was in fashion too. Of more drastic measures mention is made of 'boring the? skull with an instrument to let out the fuliginous vapours.' I wonder what Burton would say of our modern practice of prefrontal leucotomy ?

The importance of combating insomnia is not omitted and finally this long partition on therapy ends with a catalogue of remedies to expel wind.

Love melancholy is the main theme of the last partition. Burton, with customary thoroughness, anatomizes the subject from every possible aspect. Previously when discussing the symptoms of women's melancholy he rather abruptly pulls himself up. 'What have I to do with nuns, maids, virgins, widows? I am a bachelor myself, and lead a monastic life in a college.' But now he defends himself on the plea that 'an old, a grave discreet man is fittest to discourse on love matters because he hath likely more experience, observed more, hath a more staid judgement, can better discern, resolve, discuss, advise, give better cautions, and more solid precepts, better inform his auditors on such a subject, and by reason of his riper years sooner divert.' 'There is no doubt he was acutely aware of the drawbacks of a life of celibacy enforced on him as a cleric and a Fellow of a college, and his frustrations find more than ample scope in discoursing on a subject which, to many clerics was taboo. 'It is an unnatural and impious thing to bar men of this 
Christian liberty, too severe and inhuman an edict.'

The wealth of adjectives and epithets displayed is truly amazing. The tyranny of love over men is well illustrated in the following passage : 'For an old fool to dote, to see an old lecher, what more odious, what can be more absurd ? . . How many decrepit, hoary, harsh, writhen, bursten bellied, crooked, toothless, bald, blear-eyed, impotent, rotten old men shall you see flickering still in every place ? One gets him a young wife, another a courtesan, and when he can scarce lift his leg over a sill, and hath one foot already in Charon's boat, when he hath the trembling in his joints, the gout in his feet, a perpetual rheum in his head, " a continuate cough," his sight fails him, thick of hearing, his breath stinks, all his moisture is dried up and gone ... and very child again, that cannot dress himself, or cut his own meat, yet he will be dreaming of, and honing after wenches, what can be more unseemly ?' Similar invectives are levelled against old women, who are just as bad.

Burton is extremely bitter against the nuns and more particularly abbesses ; stories are quoted as factual information and hardly bear repetition. The torture of the man in love cannot be comprehended, 'the Spanish Inquisition is not comparable to it.'

That love is blind affords Burton another opportunity of dilating on the follies committed by the frailty of human nature. 'Though she be very deformed of herself, ill-favoured, wrinkled, pimpled, pale, red, yellow, tanned, tallow-faced, have a swollen juggler's platter face or a thin, lean, chitty face . . . goggle-eyed, blear-eyed, or with staring eyes ... have a sharp fox nose, a red nose, China flat . . . rotten teeth, black, uneven, brown teeth, beetle browed, a witch's beard, her breath stink all over her room, her nose drips winter and summer, filthy long unpared nails ... gouty legs, her ankles hang over her shoes.... If he love her once, he admires her for all this, he takes no notice of any such errors, or imperfections of body and mind; he had rather have her than any woman in the world.'

Burton concludes, 'there is no end of love's symptoms, 'tis a bottomless pit.' Cure for love melancholy is first of all ' to be always occupied, seriously intent.' A lean diet is prescribed and young men should refrain from reading the Book of Genesis. All kinds of subterfuges are devised to put the unfortunate man off; think of what the fair maiden will be like when she grows old, ' one grows too fat, another too lean.' He proceeds to give us an example of alliteration, which might well adorn any textbook of grammar: 'modest Matilda, pretty pleasing Peg, sweet singing Susan, mincing merry Moll, dainty dancing Doll, neat Nancy, jolly Joan, nimble Nell, kissing Kate, bouncing Bess, fair Phillis, fiddling Frank, tall Tib, slender Sib, etc., they all quickly lose their grace, grow fulsome, stale, sad, heavy, dull, sour and all at last out of fashion.' He is outrageously one-sided, 'I will say nothing of dissolute and bad husbands, of bachelors and their vices ... . and lest I should mar any matches, or dishearten loving maids, for this present I will let them pass!'

Yet, in spite of this recital of the many pitfalls that beset us, he comes to the conclusion after all ' the last refuge and surest remedy ... when no other means will take effect, is to let them go together and enjoy one another.'

Space does not allow the discussion of religious melancholy, which is regarded as a branch of love melancholy, largely due to the concept held in Burton's age that the deprivation of love-God's love-was a cause of melancholy. This review, however, would be incomplete without some - reference to the current views on folk-lore and demonology. The book is a mine of information regarding both. We read how at Hamel, in Saxony, 'An. I484, 20 Junii, the devil in likeness of a pied piper, carried away 130 children that were never after seen.' Cardan relates of his father that in 'An. I49I, I3 August, he conjured up seven devils, in Greek apparel, about 40 years of age, some ruddy of complexion, and some pale, as he thought, he asked them many questions, and they made ready answer, that they were aerial devils, that they lived and died as men did; save that they were far longer lived ( 700 or 800 years).'

Then there is the sad story of Katherine Gualter, a cooper's daughter, An. 157I, 'that had such strange passions and convulsions, three men could not sometimes hold her; she purged a live eel, which he (Cornelius Gemma, the narrator) saw a foot and a half long, and touched it himself; but. the eel afterwards vanished; she vomited some 24 pounds of fulsome stuff of all colours, twice a day for 14 days ; and after that she voided great balls of hair, pieces of wood, pigeons' dung, parchment, goose dung, coals ; and after them 2 pounds of pure blood, and then again coals and stones, of which some had inscriptions bigger than a walnut.... This I saw with horror. They could do no good on her by physick, but left her to the clergy.'

We read of aerial spirits, how such a one was bound to Cardan's father for 28 years. 'The air is not so full of flies in summer as it is at all times of invisible devils.'

For Chorus sancti viti, or St. Vitus' dance, it was still a prevailing practice in Germany for musicians to be hired to play to them and some lusty sturdy companions to dance with them. 
Some stories, however, were even too much for Burton, who quotes, with his tongue in his cheek, the story of the Roman Prince and the Jewish Rabbi who was asked why the Jew's God was compared to a lion. The reply came that it was no ordinary lion but one in the Wood Ela which, when he asked to see it, the Rabbi prayed to God he might, "and forthwith the lion set forward. But when he was 400 miles from Rome he so roared that all the great-bellied women in Rome made abortions, the City walls fell down, and he came a hundred miles nearer, and roared a second time, their teeth fell out of their heads, the Emperor himself fell down dead, and so the lion went back.'

In contrast to these myths we are provided with a deal of factual information here and there. For instance we know that Philip, the French king, who married the King of Denmark's daughter, sent her back to her father after the first night because her breath stunk. The strict observance of ritual with its severe discipline led to the martyrdom in 1270 of a Jew who "fell into a privy upon a Saturday and without help could not possibly get out; he called to his fellows for succour, but they denied it, because it was their Sabbath; the bishop hearing of it the next day forbade him to be pulled out because it was our Sunday. In the meantime the wretch died before Monday.'

So we have wandered at random through the pages of this remarkable book which, in some ways, might be regarded as one of the earliest books written in English on psychiatry. Jordan Smith writes, ' his great book is the enduring expression of a widely read scholar, of a clever craftsman, who had the genius to knit together threads from as thousand looms and thus to make a fine, stout $\stackrel{\mathbb{Q}}{\complement}$ pattern all his own.'

We have heard how Burton used to go down to $\overrightarrow{\overrightarrow{\mathrm{S}}}$ the Bridge-foot at Oxford and listen to the bargees and how for three years he was a Clerk to $\bar{\sigma}$ the Market; he was a keen student of human $\frac{\bar{c}}{\bar{m}}$ nature.

His concept of melancholy embraced a much \% wider field of mental disorders than we would accept today. He describes the hysteric and illustrates many other types in whom the prominent symptoms are hallucinations, delusions, perversions and compulsions. Nevertheless the apprehension and fear experienced by the melan- 3. cholic is very real and far from 'imaginary,' the sense of unworthiness and the narrow margin ${ }^{\prime}$ between the pathological and the normal is fully? realized. 'Some are so gently melancholy, that in $\vec{\varphi}$ all their carriage, and to the outward apprehension 6

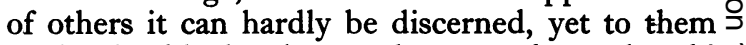
an intolerable burden, and not to be endured.' $\rightarrow$ Many of his ideas on therapy are fundamentally sound and he is fully alive to the conflicts and repressions of the mind. The need for social $\vec{\varphi}$ reform as outlined in the Utopia he describes, is indeed applicable to our present-day protoㅇㅇㅇ lems.

\section{BIBLIOGRAPHY}

BLACKWOOD, Vol. $90,323,186 \mathrm{r}$.

BURTON, Anatomy of Melancholy, edited by A. R. Shilleto, Georgə Bell \& Sons, 1896.

EVANS, Bergen Psychiatry of Robert Burton, Columbia Univ. Press, 1944.

JORDAN-SMITH, PAUL, Bibliographia Burtoniana, Stanford Univ. Press, 1931.

\section{MODERN THERAPY OF THYROTOXICOSIS}

By J. F. Goodwin, M.D., M.R.C.P.

From the Department of Pharmacology and Therapeutics, University of Sheffield, and the Royal Infirmary, Sheffield.

In 1943, Astwood and his associates, on the basis of animal experiments, concluded that thiourea and its derivatives inhibited the synthesis of thyroxin and that the resultant deficiency of thyroxin resulted in an increased output of pituitary thyrotropin, which produced thyroid hyperplasia. This thyroid hyperplasia was not influenced by large amounts of iodine but was abolished by the administration of thyroid powderc and by hypophysectomy. There was also almost complete disappearance of iodine from the thyroid? gland after five days on thiouracil, suggesting $\frac{T}{T}$ that thiouracil interfered with enzyme systems necessary for the normal conversion of di-iodotyrosine to thyroxin.

Later in 1943, Astwood investigated other re- 